\title{
Doğal Olarak Yayılış Gösteren Lepidium draba L. Türünün Fitoremediasyon Yönteminde Kullanılabilirliğinin Araştırılması
}

\author{
Dudu Duygu Kılıç ${ }^{1}$, Burak Sürmen ${ }^{2 *}$, Hamdi Güray Kutbay ${ }^{3}$, Emine Ebru Tuna ${ }^{4}$ \\ 1 Amasya Üniversitesi, Fen Edebiyat Fakültesi, Biyoloji Bölümü, Amasya, Türkiye (ORCID: 0000-0001-6425-6062) \\ 2 Karamanoğlu Mehmetbey Üniversitesi, Kamil Özdağ Fen Fakültesi, Biyoloji Bölümü, Karaman, Türkiye (ORCID: 0000-0002-4055-613X) \\ 3 Ondokuz Mayıs Üniversitesi, Fen Edebiyat Fakültesi, Biyoloji Bölümü, Samsun, Türkiye (ORCID: 0000-0001-9511-9159) \\ ${ }^{4}$ Amasya Üniversitesi, Fen Edebiyat Fakültesi, Biyoloji Bölümü, Amasya, Türkiye (ORCID: 0000-0001-6425-6062)
}

(İlk Geliş Tarihi 25 Eylül 2019 ve Kabul Tarihi 28 Ekim 2019)

(DOI: $10.31590 /$ ejosat.624424)

ATIF/REFERENCE: Kılı̧̧, D. D., Sürmen, B., Kutbay, H. G. \& Tuna, E. E. (2019). Doğal Olarak Yayılış Gösteren Lepidium draba L. Türünün Fitoremediasyon Yönteminde Kullanılabilirliğinin Araştırılması. Avrupa Bilim ve Teknoloji Dergisi, (17), 491-499.

$\ddot{\mathbf{O z}}$

Çalışmanın amacı doğal olarak yayılış gösteren Lepidium draba L., türünün fitoremediasyon yönteminde kullanılabilirliğinin araştırılmasıdır. Bu çalışmada Amasya ilinde şehir içi, otoyol, kenar semt ve kontrol olmak üzere 4 lokaliteden 5 farklı örnekleme yapılmıştır. Bitki örnekleri, 2015-2016 yıllarında Ağustos ayı sonunda (vejetatif dönemin sonu) toplandı. Toprakta ortalama olarak ağır metal birikim miktarları $\mathrm{Fe}>\mathrm{Mn}>\mathrm{Co}>\mathrm{Ni}$ olarak tespit edilmiştir. Buna göre en yüksek ağır metal konsantrasyonları, trafik yoğunluğu olan şehir içinde bulunmuştur. Topraklarda zenginleşme faktörüne göre, Fe ve Mn belirgin zenginleşme sınıfına girmektedir. Jeobirikim indeksine göre; örnek alınan alanlar Ni, Co, Mn bakımından kirlenmemiş, Fe bakımından ise yol kenarı, kenar semt ve kontrol grubunda orta derece kirlenmiş iken şehir içinde orta-çok kirlenmiş olarak sınıflanmaktadır. Bitkide ortalama olarak ağır metal birikim miktarları $\mathrm{Fe}>\mathrm{Mn}>\mathrm{Ni}>\mathrm{Co}$ olarak tespit edilmiştir. Ni bitki ve toprakta toksik sınırın altında, Fe bitkide ve toprakta sınır değerin üstüne, Co bitkide ve toprakta sınır değerin üstüne, Mn ise toprakta sınır değerinin altında iken şehiriçi, yol kenarı ve kenar semt lokalitelerinde toksik sınırın üstünde bulunmuştur. L.draba Ni ve Fe'nin köklerde birikimi, Co ve Mn ise yaprakta birikimin daha yüksek olduğu görülmektedir. Trafik yoğunluğunun yüksek olduğu şehir içinde ağır metal birikimi daha yüksek bulunmuştur. Şehir merkezinde (BCF> 1) 1' den daha yüksek BCF değerleri bulunmuş olup, yol kenarında Co dışında diğer elementlere ait BCF ve TF değeri 2'nin üstündedir. Şehir merkezi ve yol kenarında en fazla akümüle edilen element Fe olarak bulunmuştur. Buna göre $L$. draba türünün TF ve BCF değerleri yüksek bulunmuş olup bitkinin hiperakümülatörlük özelliğinin yüksek olduğu tespit edilmiştir.

Anahtar Kelimeler: L. draba, Ağır metal, hiperakümülatör, Amasya, Türkiye.

\section{Investigation of Heavy Metal Accumulation and Biomonitoring of Lepidium draba L. Species Growing in Amasya (Turkey) Province}

\begin{abstract}
The aim of study was to investigate the usability of the naturally growing Lepidium draba L. species in phytoremediation method. Five different samples were taken from four different localities (city centre, highway, suburban and control) in Amasya. Plant samples were collected at the end of the vegetative period of the Lepidium draba in 2015-2016. The average concentration of heavy metal accumulation in the soil was determined as $\mathrm{Fe}>\mathrm{Mn}>\mathrm{Co}>\mathrm{Ni}$. Accordingly, the highest heavy metal concentrations were found in the
\end{abstract}

${ }^{*}$ Sorumlu Yazar: Karamanoğlu Mehmetbey Üniversitesi, Kamil Özdağ Fen Fakültesi, Biyoloji Bölümü, İstanbul, Türkiye, ORCID: 0000-00000000-0000, buraksurmen@,gmail.com 
city. According to the soil enrichment factor, Fe and Mn belong to significant enrichment class. The sample areas considering geoaccumulation index are uncontaminated with $\mathrm{Ni}, \mathrm{Co}, \mathrm{Mn}$, but roadside, suburban and control sample areas are moderately contaminated with Fe, the city sample area is contaminated with Fe as moderately and highly. The average amount of heavy metal accumulation in the plant was determined as $\mathrm{Fe}>\mathrm{Mn}>\mathrm{Ni}>\mathrm{Co}$. Ni concentraitons were found below the toxic limit in plant and soil, $\mathrm{Fe}$ concentraitons were found above the limit value in plants and soil, Co concentraitons were found above the limit value in plants and soil. While Mn concentraiton was below the limit value in soil, it was found above the toxic limit in urban, roadside and suburbs. Ni and $\mathrm{Fe}$ accumulaions were detected high concentrations in roots and $\mathrm{Co}$ and $\mathrm{Mn}$ accumulaions were detected high concentrations in leaves. Heavy metal accumulation was found to be higher in the city due to high traffic density. BCF values were calculated higher than one in the city center and BCF and TF values of other elements except Co were calculated above two. The most accumulated element was found as $\mathrm{Fe}$ in the city center and roadside. As a result, TF and BCF values and hyperacumulatory properties of $L$. draba were found to be high.

Keywords: L. draba, heavy metal, hyperaccumulator, Amasya, Turkey.

\section{Giriș}

Ağır metal kirliliği en önemli çevre kirliliklerinden biridir. Fiziksel özellik açısından yoğunluğu $5 \mathrm{gr} / \mathrm{cm}^{3}$ ' ten daha yüksek olan metaller ağır metaller olarak adlandırılır ve doğada Bakır $(\mathrm{Cu})$, Demir (Fe), Çinko (Zn), Kurşun (Pb), Civa (Hg), Kobalt (Co), Krom (Cr), Nikel (Ni) ve Kadmiyum (Cd) başta olmak üzere 53'den fazla ağır metal bulunmaktadır (Kılıç, 2019). Ağır metalleri canlılar için gerekli olan ve olmayan şeklide sınıflandırmak mümkündür. Bu elementlerin bir kısmı canlılık faaliyetleri için gerekli iken yüksek dozda toksik etki gösterebilmektedirler (Doğan ve ark., 2018). Genellikle ağır metaller doğaya, doğal yollarla yani ağır metal içeren kayalardan ve madenlerden karışmaktadır. Yapay yollarla karışması ise daha çok endüstri, tarımsal faaliyetler ve trafik yolu ile olup, gün geçtikçe artan hava, su ve toprak kirliliğe neden olmaktadır (Demirayak ve ark., 2019). Kirlenmiş toprak ve havadan bulaşan ağır metaller besin zinciri yoluyla tüm canlıları tehdit etmektedir. Topraktan alınan ağır metallerin bitkilerin doku ve organlarında birikmesi, bitkilerin vejetatif ve generatif organlarının gelişimini olumsuz etkilemektedir. Ayrıca bitkilerde transpirasyon, stoma hareketleri, su alımı, fotosentez, enzim aktivitesi, çimlenme, protein sentezi, membran stabilitesi, hormonal denge gibi pek çok fizyolojik olayın da olumsuz olarak etkilenmesine sebep olmaktadır (Doğan, 2018). Örneğin; bitkide gereğinden fazla bulunan Ni, klorofil sentezi ve yă̆ metabolizması üzerine olumsuz etki yapar, bitki köklerinin diğer besin elementlerini almasını engelleyerek besin elementleri noksanlıklarının ortaya çıkmasına neden olur (Asri ve Sönmez, 2006). Yine bitkide fotosentez reaksiyonlarında görev alan mangan eksikliğinde bitkinin lipit kapsamı ve tohum bileşiminde büyük değişiklikler görülür. Mn toksistesinde ise vejetatif ve generatif organların gelişimi yavaşlar ve $\mathrm{N}$ fiksasyonu engellenir (Kaçar ve Katkat, 2010). Canlılarda demir önemli elementlerden biridir hemoglobinin ve enzimlerin yapısına katılarak DNA sentezi, solunum ve fotosentez gibi metabolik süreçlerde önemli rol oynar. Bitkilerde klorofil yapımını destekler ve $\mathrm{N}$ fiksasyonunda görev alır. Fe toksitesinde bitkide vejetatif ve generatif yapılarda gelişme geriliği görünmektedir. Kobaltın insanlar, hayvanlar ve prokaryotlar için temel bir element olduğu uzun yıllardır bilinmesine rağmen, bu element için daha yüksek bitkilerde biyolojik bir fonksiyon tanımlanmamıştır (Oven ve ark., 2002). Son yıllarda bazı çalışmalarda Fitoflatin (PC) Sentaz enziminin yapısına katıldığı bildirilmiş (Vatamaniuk ve ark., 2000) olsa da diğer çalışmalar bu veriyi desteklememektedir (Oven ve ark., 2002). Kobalt PC-sentazı aktive etmediğinden, bitkiler kobalt iyonlarının hücresel proteinler üzerindeki toksik etkisini önlemek için farklı bir detoksifikasyon mekanizması geliştirmiş olmalıdır. Ağır metaller küresel kirlilik faktörü olarak tüm canlılar üzerinde büyük tehlike oluşturmaktadır. Ağır metaller, insanlar tarafından maruz kalınan doz oranı, kişinin bağışıklık ve genel sağlık durumu gibi çeşitli faktörlere bağlı olarak insanlarda başta kanser olmak üzere birçok hastalığın başlama ve ilerlemesinde etken olmaktadır (Kabata-Pendias ve Dudka, 1991).

Ağır metal ile kirlenmiş toprakları ve su kaynakları rehabilite etmek için fiziksel, kimyasal ve biyolojik yöntemler kullanılmaktadır. Fiziksel ve kimyasal yöntemler hem pahalı hem de yeniden doğayı kirletebilecek yöntemleri içermektedir (Luu ve ark., 2009). Biyolojik yöntemlerde canlıların kullanılması hem ucuz hem de çevre dostu bir yöntem olarak bilinmektedir. Ağır metallerle kirlenmiş alanların iyileştirilmesinde kullanılan pahalı ve daha fazla uğraş gerektiren geleneksel mühendislik yöntemleri olan remediasyon teknikleri yerine (Salt ve Rauser, 1995) son yıllarda maliyeti daha düşük teknik, çevre dostu olan yeşil ıslah (fitoremediasyon) teknolojisi kullanılmaktadır. Fitoremediasyonun, kirlenmiş doğal ortamların iyileştirilmesi için etkin bir yöntemdir (Garbisu ve ark., 2002 ). Hiperakümülatörler, canlı dokularında belirli metalleri veya metaloidleri, çoğu bitkiden normalden yüzlerce veya binlerce kat daha fazla olan seviyelerde biriktiren sıra dışı bitkilerdir (Reeves, 1983; van der Ent ve ark., 2016). Bu bitkiler sürgünlerinde metalleri biriktirerek metallere karşı aşırı tolerans gösterirler (McGrath ve ark., 2001). Bir hiperakacumülatör bitkinin sınıflandırılması için bir başka gereklilik, bitkilerde bulunan konsantrasyonların kirlenmemiş ortamlarda yetişen bitkilerden 10 ila 500 kat daha yüksek olması gerektiğidir (Yanqun ve ark., 2005).

Literatürde 400'den fazla hiperakümülatör bitki türü olduğu belirtilmektedir. Hiperakümülatör bitkilerin, o çevredeki doğal bitki örtüsünün bir elemanı olması tercih edilmelidir. Bir hiperakümülatör bitkinin topraktan uzaklaştırdığı ağır metal miktarı, bitkinin dokularında biriktirdiği metalin derişiminin, bitkinin ürettiği biyokütle miktarına bölünmesiyle bulunur (Macek ve ark., 2008). Fitoremediasyon; çevrede bulunan kirleticilerin alınmasında veya bu kirleticilerin etkisiz hale getirilmesinde hiperakümülatör bitkilerin kullanılmasıdır. Fitoremediasyon kapsamında söz konusu olan yöntemler; fitoekstraksiyon, fitostabilizasyon, fitovolatilizasyon, Rizodegredasyon, fitodegradasyon, rizofiltrasyon olarak adlandırılırlar (Yoon ve ark., 2006). Bu çalışmanın amacı, Amasya ilinde doğal olarak yayılış gösteren Lepidium draba L., türünün fitoremediasyon yönteminde kullanılabilirliğinin araştırılmasıdır. 


\section{Materyal ve Metot}

\subsection{Araştırma alanı}

Bu çalışma, Türkiye'nin Orta Karadeniz Bölgesi'nde yer alan Amasya ilinde gerçekleştirilmiştir. Araştırma alanının denizden ortalama yüksekliği 412 m'dir. Türkiye'nin Karadeniz bölgesinde bulana Amasya ili 3457'06" - 36²31'53" doğu boylamları ile

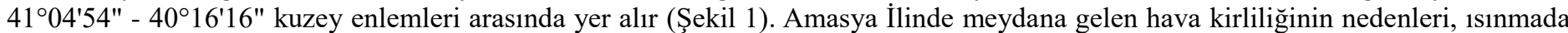
kullanılan yakıtlar, motorlu taşıtlardan kaynaklanan egzoz gazı emisyonları, sanayiden kaynaklanan emisyonlar olarak sıralanabilir. Şehir içinde dağlar nedeni ile hava akımı daha az olduğu için hava kirliliği şiddetli yaşanmaktadır ayrıca Amasya ilinde çevre yolunun olmaması şehir içi trafiği arttırmakta dolayısı ile trafik kaynaklı kirlilik oranı artmaktadır.

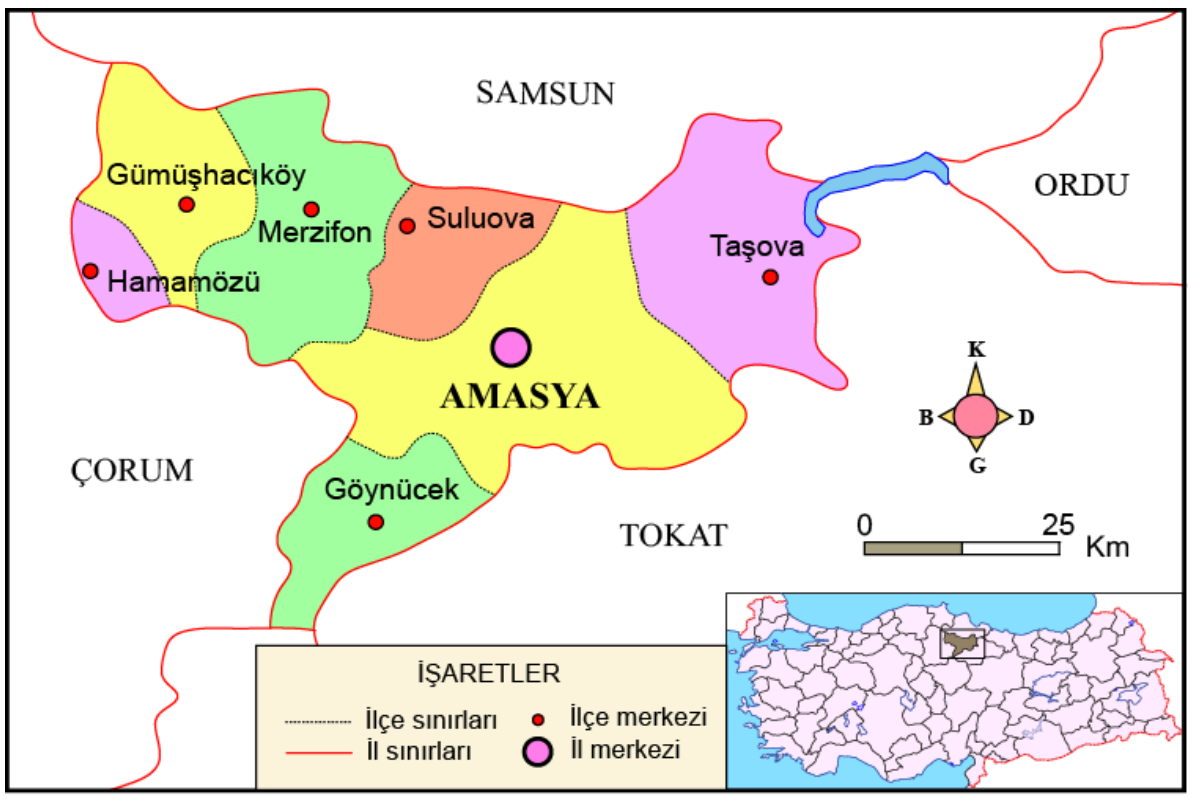

Şekil 1. Araştırma alanının haritası

\subsection{Lepidium draba'nın morfolojik karakterleri}

Lepidium draba, Brassicaaceae familyasına ait çok yıllık 15-90 cm uzunluğunda sürünen bir yabani ottur. Bu yabani ot temelde Balkan Yarımadas1, Gürcistan, Ermenistan, İsrail, Rusya, Türkiye ve Güney Avrupa’ya özgüdür. Genellikle Killi-kumlu, nemli topraklarda ve gölge kısımlarda hızlı büyüyen bir bitkidir. Yol kenarı, hendek kıyıları, meralar gibi nemli yerlerde yetişen bir bitki türüdür (Afzal ve ark., 2016). Yaprakları dikdörtgensi, sivri uçlu, düzensiz derin dişli, grimsi yeşil renkli olup, gövdeyi sarar ve yaprak kenarları dişlidir. Çiçekleri nisan, mayıs ve haziran aylarında ayında açar, beyaz ve hermafrodit'tir. Çiçekler çok dallı, şemsiyemsi kümeler oluşturan, yoğun öbekler halinde ve küçüktür. L. draba meyvesi 3-4 mm uzunluğundadır ve ters çevrilmiş bir kalp şeklindedir (Scurfield, 1962).

\subsection{Bitki örneklemesi}

Bitki örneklemesi 2015-2016 yıllarında bitkinin vejetatif döneminin sonu olan Ağustos ayında; şehir içi, otoyol, kenar semt ve kontrol olmak üzere 4 lokaliteden 5 farklı örnekleme yapılmıştır. Her bir noktanın koordinatları, GPS (Global Positioning System) konumlandırma sistemi) aleti ile tespit edilip kaydedilmiştir (Tablo 1).

Tablo 1. Araştırma yapılan alanlar

\begin{tabular}{|c|c|c|}
\hline Lokalite & Koordinat & Trafik yoğunluğu \\
\hline Amasya Suluova Otoyolu & $40^{\circ} 45^{\prime} 09.5^{\prime \prime} \mathrm{N} 35^{\circ} 44^{\prime} 05.4^{\prime \prime} \mathrm{E}$ & $\begin{array}{l}\text { Otomobil, Orta Yüklü Ticari Taşıt Otobüs, Kamyon } \\
\text { Kamyon+Römork,Çekici+Yan Römork } \\
(8515+441+310+887+1138=11291)\end{array}$ \\
\hline Şehir içi & $40^{\circ} 40^{\prime} 06.4^{\prime \prime} \mathrm{N} 35^{\circ} 50^{\prime} 36.2^{\prime \prime} \mathrm{E}$ & $\begin{array}{l}\text { Otomobil, Orta Yüklü Ticari Taşıt Otobüs, Kamyon } \\
\text { Kamyon+Römork,Çekici+Yan Römork } \\
(12203+1461+161+1763+613=16201\end{array}$ \\
\hline Kenar Semt (Orman Bağları) & $40^{\circ} 36^{\prime} 09.9^{\prime \prime} \mathrm{N} 35^{\circ} 48^{\prime} 48.5^{\prime \prime} \mathrm{E}$ & Dakikada 3-5 araç \\
\hline Kontol (Aydınca kırsalı) & 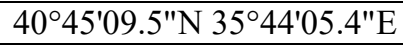 & Trafik Yok \\
\hline
\end{tabular}

\subsection{Hesaplamalar ve istatistik analizler}

Örneklerden elde edilen veriler SPSS 15 paket programı kullanılarak analiz edildi. Şehiriçi, yol kenarı, kenar semt ve kontrol (trafik olmayan alan) lokalitelerinin toprak ve bitki değişkenlerindeki farklılıkları karşılaştırmak için tek yönlü varyans analizi (ANOVA) kullanılmıştır. İkili karşılaştırmalarda Anlamlı farklılıkların hangi değişkenler arasında olduğunu belirlemek amacıyla 
Tukey HSD testi kullanılmıştır. Topraktaki ağır metaller ile bitki kökü ve sürgündeki ağır metaller arasındaki ilişkiyi değerlendirmek için basit doğrusal korelasyon katsayısı kullanılmıştır.

Toprak ağır metal zenginleştirme faktörü (ZF), Topraktaki antropojenik katkı sebebiyle oluşmuş ağır metal kirliliğini belirlemek için kullanılan bir göstergedir (Buat-Menard ve Chesselet, 1979; Barbieri, 2016; Özkul ve ark., 2018).

$Z F=(\text { Cn/Cref })_{\text {örnek }} /(B n / \text { Bref })_{\text {referans }}$

Formülde, Cn: Analizi yapılan örnekteki elementin değeri; Cref: Analizi yapılan örnekteki referans elementin değeri; Bn: Brooks (1972)'a göre elementin topraktaki ortalama değeri; Bref: Brooks (1972)'a göre referans elementin topraktaki ortalama değeri olarak kullanılmıştır. Bu çalışmada referans element olarak Mn kullanıştır.

Jeo birikim İndeksi (Geoaccumulation Index, Igeo), topraktaki ağır metal kirlilik seviyesini ölçmek için endüstrileşme öncesi element değerlerinin günümü değerleri ile karşılaştırmak için Müller (1969) tarafından önerilmiştir (Barbieri, 2016).

$I_{\text {geo }}=\log _{2}(\mathrm{Cn} /(1.5 * \mathrm{Bn})$ edilir.

Burada Cn: Çalışılan örnekteki ağır metal konsatrasyonu, Bn: n metalinin topraktaki ortalama değeri Brooks (1972) olarak ifade

Fitoremediasyon amacıyla yetiştirilecek bitkilerin seçiminden BCF ve TF değerleri ile değerlendirilir. Bitkilerce element alımlarının büyüklüğü, Biriktirme Faktörü (Bioconcentration factor, BCF) cinsinden ifade edilmektedir. Biriktirme faktörü bitkideki ağır metal derişiminin, topraktaki ağır metal derişimine oranlanmasıyla hesaplanmaktadır (Ladislas ve ark., 2012).

Biyoakümülasyon faktörü $(\mathrm{BCF})=$ Hasat edilen bitkideki ağır metal derişimi/Toprak ağır metal derişimi

Bitkilerin metal alım ölçüsünü ifade eden diğer bir gösterge ise Taşıma Faktörü'dür (Translocation Factor, TF). Taşıma faktörü ağır metallerin kökten üst organlara doğru hareketinin bir göstergesidir ve bitkinin gövdesindeki ağır metal derişiminin, köktekine oranlanmasıyla hesaplanmaktadır (Padmavathiamma ve Li, 2007).

Translokasyon faktörü (TF) = Sürgün ağır metal derişimi/Kök ağır metal derişimi

\section{Araştırma Sonuçları}

Çalışılan lokalitelerde toprak ve bitki türünün toplam ağır metal içerikleri ve Tukey's HSD testi sonuçları tablo 2'de verilmiştir. Toprakta ortalama olarak ağır metal birikim miktarları $\mathrm{Fe}>\mathrm{Mn}>\mathrm{Co}>\mathrm{Ni}$ olarak tespit edilmiştir. Buna göre en yüksek ağır metal konsantrasyonları, trafik yoğunluğunun meydana geldiği şehir merkezinde bulunmuştur (Şekil 2). Toprakta ise Ni kontrol grubunda, Fe şehir merkezinde, Co ve Mn yol kenarında yüksek olup toprak $\mathrm{pH}^{\prime} \mathrm{s} 1$ yol kenarında ki topraklarda yüksek bulunmuştur. Şehir içi ve otoyol kenarındaki ağır metal içeriklerinin farklılıkları ise önemli bulunmuştur.

Tablo 2. L.draba türünün yetiştiği topraklardaki ağır metal miktarı (ppm) ve lokalitelere göre ağır metal değerlerinin farklılıklarına ait Tukey testi sonuçları (Küçük harfler $\mathrm{P}<0.05$ düzeyinde farklılıkları gösterir)

\begin{tabular}{lllllllllll}
\hline \multicolumn{3}{c}{ Bitki } & \multicolumn{1}{c}{ Toprak } \\
\hline & $\mathbf{N}$ & $\boldsymbol{N i}$ & $\boldsymbol{F e}$ & $\boldsymbol{C o}$ & $\boldsymbol{M n}$ & $\boldsymbol{N i}$ & $\boldsymbol{F e}$ & $\boldsymbol{C o}$ & $\boldsymbol{M n}$ & $\boldsymbol{p H}$ \\
\hline Kontrol & 60 & $2.86 \mathbf{c}$ & $6.33 \mathbf{c}$ & $1.79 \mathrm{c}$ & $40.83 \mathbf{d}$ & $3.37 \mathbf{a}$ & $44.12 \mathbf{d}$ & $3.69 \mathbf{b}$ & $78.62 \mathbf{b c}$ & $7.67 \mathbf{c}$ \\
\hline Kenar semt & 60 & $4.46 \mathbf{c}$ & $26.79 \mathrm{c}$ & $3.72 \mathbf{b}$ & $118.87 \mathbf{c}$ & $2.68 \mathbf{b}$ & $53.79 \mathbf{c}$ & $3.37 \mathbf{b}$ & $67.86 \mathbf{c}$ & $7.82 \mathbf{b}$ \\
\hline Otoyol kenarı & 60 & $14.98 \mathbf{b}$ & $4936.34 \mathbf{b}$ & $2.79 \mathbf{a b}$ & $270.57 \mathbf{b}$ & $3.32 \mathbf{a}$ & $442.19 \mathbf{b}$ & $4.30 \mathbf{a}$ & $96.72 \mathbf{a}$ & $8.12 \mathbf{a}$ \\
\hline Şekir içi & 60 & $32.25 \mathbf{a}$ & $11100.36 \mathbf{a}$ & $9.19 \mathbf{a}$ & $556.57 \mathbf{a}$ & $2.86 \mathbf{b}$ & $510.16 \mathbf{a}$ & $4.24 \mathbf{a}$ & $89.87 \mathbf{a b}$ & $7.53 \mathbf{d}$ \\
\hline
\end{tabular}

Topraklarda Zenginleşme Faktörü, Sutherland (2000) tarafından "EF $<2$; Minimal zenginleşme, $2 \leq \mathrm{EF} \leq 5$; Orta zenginleşme, $5 \leq \mathrm{EF} \leq 20$; Belirgin zenginleşme, $20 \leq \mathrm{EF} \leq 40$; Çok yüksek zenginleşme, $\mathrm{EF}>40$; Aşırı zenginleşme" şeklinde sınıflandırılmıştır. Buna göre çalışmamızda topraktaki Fe ve Mn belirgin zenginleşme sınıfina girmektedir. Endüstri öncesi ve sonrası kirlilik karşılaştırması yapan Jeobirikim indeksi 7 kategoriye ayrılmıştır. Buna göre Igeo $<0$; kirlenmemiş, $0<$ Igeo $<1$; Kirlenmemiş-orta derecede kirlenmiş; $1<$ Igeo $<2$ Orta derecede kirlenmiş; $2<$ Igeo $<3$ Orta-çok kirlenmiş; $3<$ Igeo $<4$; Çok kirlenmiş, $4<$ Igeo $<5$ Çok-aşırı kirlenmiş, Igeo $>5$; Aşırı kirlenmişşeklinde sınıflandırılmıştır (Müller, 1969; Özkul ve ark., 2018). Bu çalışmada jeobirikim indeksine göre örnek alınan alanlar $\mathrm{Ni}, \mathrm{Co}, \mathrm{Mn}$ bakımından kirlenmemiş, Fe bakımından ise yol kenarı, kenar semt ve kontrol grubunda orta derece kirlenmiş iken şehir içinde orta-çok kirlenmiş olarak sinıflanmaktadır (Tablo 3).

Tablo 3. Lokalitelere göre toprakların zenginleşme faktörü (ZF), Jeobirikim (Igeo değeri)

\begin{tabular}{lllll}
\hline Lokalite & Şehir içi & Ototol kenarı & Kenar semt & Kontrol \\
\hline ZF-Ni & 0.3523 & 1.0310 & 1.1587 & 1.2517 \\
\hline ZF-Fe & 7.4289 & 14.3872 & 17.5549 & 3.5452 \\
\hline ZF-Co & 0.4797 & 1.1563 & 1.3338 & 1.4194 \\
\hline ZF-Mn & 9.6068 & 24.7949 & 27.6713 & 30.8179 \\
\hline Igeo-Ni & -4.4791 & -4.2394 & -4.6817 & -4.1674 \\
\hline Igeo-Fe & 2.1837 & 1.9436 & 1.8034 & 1.5555 \\
\hline
\end{tabular}

e-ISSN: 2148-2683 


\begin{tabular}{lllll}
\hline Igeo-Co & -1.8580 & -1.8331 & -2.2249 & -2.0363 \\
\hline Igeo-Mn & -3.8463 & -3.7973 & -4.8077 & -4.0860 \\
\hline
\end{tabular}

Araştırılan alandan alınan toprak değerleri ile $L$. draba türünün kök gövde ve yapraklarında yapılan ağır metal analiz sonuçları aşağıda verilmiştir (Şekil 2).

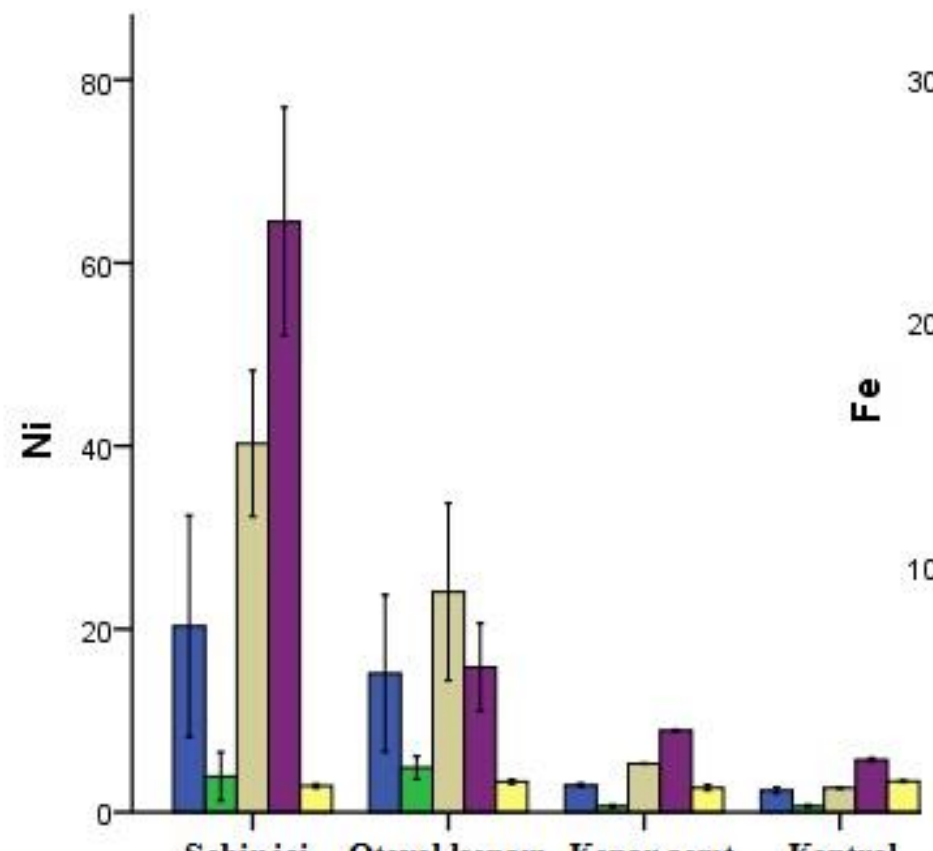

Șehir içi Otoyol kenarı Kenar semt Kontrol
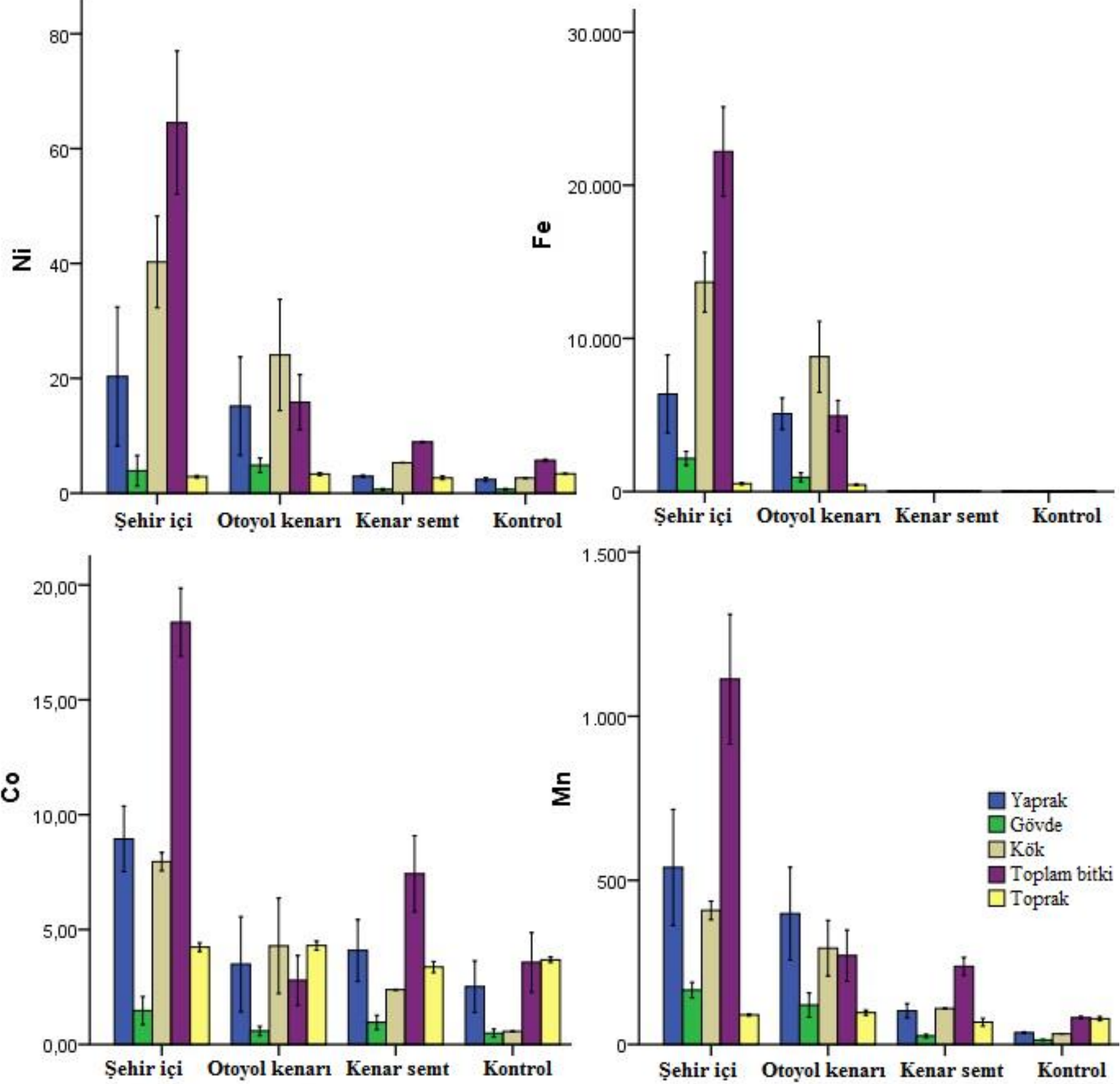

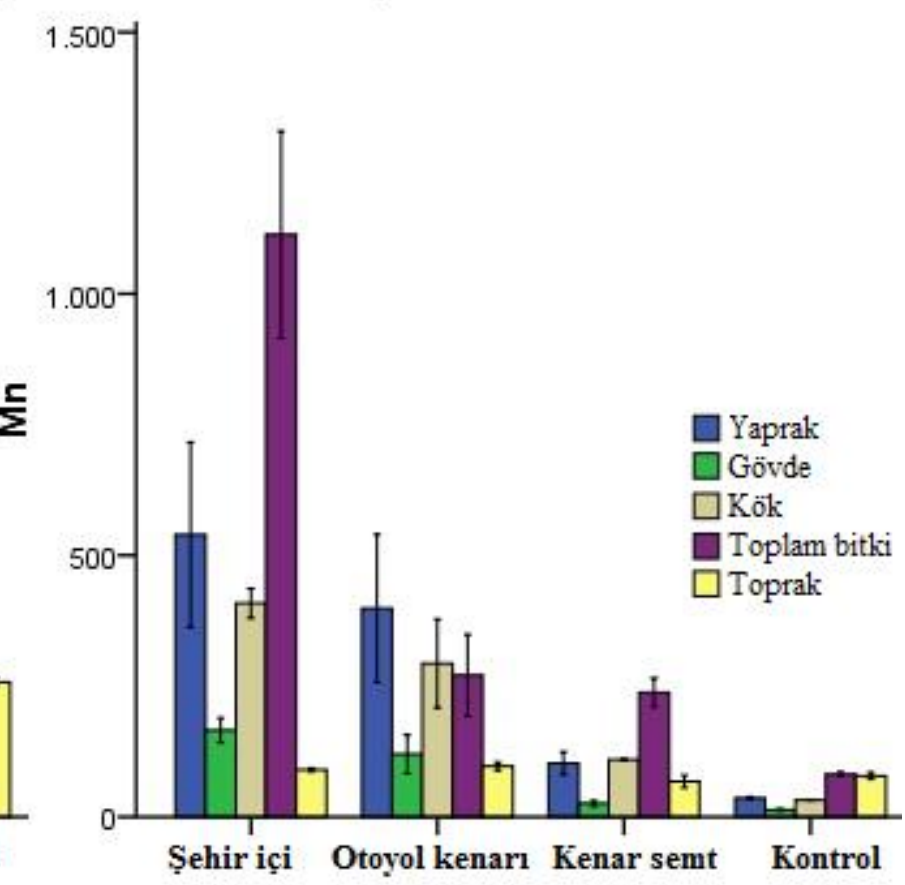

Şekil 2: L.draba türünün lokalitelere göre bitkide ve toprakta biriken ağır metal miktarları Ni, Fe, Co, Mn (ppm)

Bitkide ortalama olarak ağır metal birikim miktarları $\mathrm{Fe}>\mathrm{Mn}>\mathrm{Ni}>\mathrm{Co}$ olarak tespit edilmiştir. L.draba Ni ve Fe'nin köklerde birikimi, Co ve Mn ise yaprakta birikimin daha yüksek olduğu görülmektedir. Trafik yoğunluğunun yüksek olduğu şehir içinde ağır metal birikimi daha yüksek bulunmuştur. ANOVA sonuçları Tablo 4'de özetlenmiştir. Sonuçlara göre, ağır metal içerikleri bitki organları ve lokaliteler arasında önemli ölçüde değişmiştir. Toprak ağır metal içerikleri ise Fe içeriği dışında önemli bulunmamıştır $(\mathrm{P}>0.05)$. Çalışılan türün kök, gövde ve yaprakları arasında Ni, Fe, Co ve Mn elementleri bakımından arasında istatistiksel olarak farklar bulunmaktadır (Tablo 4). 
Tablo 4. Bitki kısımları ve lokaliteler dikkate alınarak apılan çok yönlü ANOVA analizi sonuçları $\left(* * \mathrm{p}<0,01,{ }^{*} \mathrm{p}<0,05\right)$

\begin{tabular}{|c|c|c|c|c|c|c|}
\hline Kaynak & $\begin{array}{l}\text { Bağımlı } \\
\text { değişken }\end{array}$ & $\begin{array}{l}\text { Tip III Kareler } \\
\text { toplamı }\end{array}$ & $\mathrm{df}$ & $\begin{array}{l}\text { Ortalama } \\
\text { kareler }\end{array}$ & F değeri & Önemlilik \\
\hline \multirow{9}{*}{$\begin{array}{l}\text { Bitki } \\
\text { kısmı }\end{array}$} & $\mathrm{Ni}$ & 15416.7 & 3 & 5138.9 & 44.56 & $0.00 * *$ \\
\hline & $\mathbf{F e}$ & 1331490572 & 3 & 443830190.6 & 81.98 & $0.00 * *$ \\
\hline & Co & 1570.03 & 3 & 523.34 & 115.56 & $0.00 * *$ \\
\hline & Mn & 3675763.69 & 3 & 1225254.56 & 55.74 & $0.00 * *$ \\
\hline & Toprak Ni & 0.95 & 3 & 0.32 & 0.42 & 0.74 \\
\hline & Toprak Fe & 1199.44 & 3 & 399.81 & 3.46 & $0.01 * *$ \\
\hline & Toprak Co & 2.13 & 3 & 0.71 & 1.32 & 0.26 \\
\hline & Toprak Mn & 1750.79 & 3 & 583.6 & 0.6 & 0.61 \\
\hline & pH & 0 & 3 & 0 & 0.8 & 0.49 \\
\hline \multirow{9}{*}{ Lokalite } & $\mathbf{N i}$ & 32935.56 & 3 & 10978.52 & 95.2 & $0.00 * *$ \\
\hline & $\mathbf{F e}$ & 4981585813 & 3 & 1660528604 & 306.71 & $0.00 *$ \\
\hline & Co & 1969.23 & 3 & 656.41 & 144.94 & $0.00 * *$ \\
\hline & Mn & 9318951.01 & 3 & 3106317 & 141.32 & $0.00 * *$ \\
\hline & Toprak Ni & 20.82 & 3 & 6.94 & 9.06 & $0.00 * *$ \\
\hline & Toprak Fe & 19961.33 & 3 & 6653.78 & 57.51 & $0.00 * *$ \\
\hline & Toprak Co & 36.07 & 3 & 12.02 & 22.31 & $0.00 * *$ \\
\hline & Toprak Mn & 29017.56 & 3 & 9672.52 & 9.88 & $0.00 * *$ \\
\hline & pH & 11.46 & 3 & 3.82 & 36660.8 & $0.00 * *$ \\
\hline \multirow{9}{*}{$\begin{array}{l}\text { Bitki } \\
\text { kısmı * } \\
\text { Lokalite }\end{array}$} & $\mathbf{N i}$ & 18871.78 & 9 & 2096.86 & 18.18 & $0.00 * *$ \\
\hline & $\mathbf{F e}$ & 2615594437 & 9 & 290621604.1 & 53.68 & $0.00^{* *}$ \\
\hline & Co & 1180.21 & 9 & 131.13 & 28.96 & $0.00 * *$ \\
\hline & Mn & 4578370.24 & 9 & 508707.81 & 23.14 & $0.00 * *$ \\
\hline & Toprak Ni & 12.27 & 9 & 1.36 & 1.78 & 0.07 \\
\hline & Toprak Fe & 3018.55 & 9 & 335.4 & 2.9 & $0.00 * *$ \\
\hline & Toprak Co & 6.49 & 9 & 0.72 & 1.34 & 0.21 \\
\hline & Toprak Mn & 7361.66 & 9 & 817.96 & 0.84 & 0.58 \\
\hline & pH & 0 & 9 & 0 & 0.8 & 0.61 \\
\hline
\end{tabular}

Tablo 5. Biyokonsantrasyon faktörleri (BCF), Translokasyon faktörleri (TF) ve Zenginleştirme Faktörleri (ZF) değerleri ve ANOVA testi $(* * \mathrm{p}<0 ., 01, * \mathrm{p}<0.05)$

\begin{tabular}{lllllll}
\hline Lokalite & Şehir içi & Otoyol kenarı & Kenar semt & Kontrol & F değeri & Önemlilik. \\
\hline TF-Ni & 0.7367 & 1.01 & 0.68 & 1.15 & 1.772 & 0.163 \\
\hline TF-Fe & 0.6835 & 0.73 & 0.43 & 0.82 & 5.401 & $0.002^{* *}$ \\
\hline TF-Co & 1.3172 & 1.45 & 2.12 & 5.36 & 9.92 & $0.00^{* *}$ \\
\hline TF-Mn & 1.7498 & 1.95 & 1.17 & 1.55 & 3.19 & $0.03^{*}$ \\
\hline BCF-Ni & 12.43 & 5.64 & 1.9 & 0.87 & 34.364 & $0.00^{* *}$ \\
\hline BCF-Fe & 23.35 & 12.24 & 0.51 & 0.14 & 154.206 & $0.00^{* *}$ \\
\hline BCF-Co & 2.3 & 0.82 & 1.25 & 0.47 & 27.756 & $0.00^{* *}$ \\
\hline BCF-Mn & 6.47 & 3.00 & 2.48 & 0.58 & 44.522 & $0.00^{* *}$ \\
\hline ZF-Ni & 8.4765 & 6.0269 & 1.3467 & 0.9082 & 9.119 & $0.00^{* *}$ \\
\hline ZF-Fe & 16.7258 & 13.5859 & 0.3037 & 0.1301 & 45.418 & $0.00^{* *}$ \\
\hline ZF-Co & 2.4572 & .9482 & 1.4985 & 0.8154 & 14.331 & $0.00^{* *}$ \\
\hline ZF-Mn & 7.8437 & 5.3488 & 1.8917 & 0.6319 & 24.743 & $0.00^{* *}$ \\
\hline
\end{tabular}

Biyokonsantrasyon faktörleri (BCF), Translokasyon faktörleri ve Zenginleştirme Faktörleri değerleri ve ANOVA testi Tablo 5 'te özetlenmiştir. BCF, bitkilerde metal birikim etkinliğinin değerlendirilmesi için ve TF ise bitkinin köklerinden üst organlarına metallerin yerini değiştirme kapasitesini değerlendirmek için kullanılır. Aşırı biriktirici (hiperakümülatör) bitkilerde TF>1 olması her zaman esastır. TF ise bitkinin köklerinden üst organlarına metallerin yerini değiştirme kapasitesini değerlendirmek için kullanılır. Buna göre Ni elementinin yol kenarında Co ve Mn elementlerin ise tüm lokalitelerde üst organlara taşınabildiği tespit edilmiştir. $\mathrm{TF}>1$, verimli metal taşıma sistemleri_nedeniyle besin maddelerini_köklerden sürgünlere taşımada çok verimli bir yetenek olduğunu göstermektedir. 
BCF değeri ne kadar yüksekse, fito-ekstraksiyon için o kadar uygun bir bitki olduğu bildirilmiştir (Blaylock ve ark., 1997). BCF değerleri ikiden büyükse yüksekdeğer olarak kabul edilir (Mellem ve ark., 2012). Zayed ve ark. (1998) ise BCF dört kategoriye ayırmışlarıdır buna göre $;<0,01$ akümülatör özelliğine sahip olmayan bitkiler, 0.01-0.1düşük derecede akümülatör özelliğine sahip bitkiler, 0,1-1,0 orta derecede akümülatör olan bitkiler, 1-10 yüksek derecede akümülatör özelliğine sahip ya da hiper akaümülatör bitkilerdir. Bu oran kullanılarak, topraktaki elementlerin bitki tarafından emilimi gösterilebilmekte ve topraktan bitkiye element geçişinin büyüklüğü niceleyici olarak tahmin edilebilmektedir (Kalender ve Alçiçek, 2016). Şehir merkezinde (BCF>1) yüksek BCF değerleri bulunmuş olup, yol kenarında Co dışında diğer elementlere ait BCF değeri 2'nin üstündedir. Şehir merkezi ve yol kenarında en fazla akümüle edilen element $\mathrm{Fe}$ olarak bulunmuştur. $L$. draba türünün $\mathrm{Ni}, \mathrm{Fe}$, Co ve $\mathrm{Mn}$ için iyi bir biyoakümülatör olduğu bulunmuştur. $L$. draba biyoakümülasyon potansiyeli ve taşıma faktörü $\mathrm{Ni}$ elementi dışında lolakiteler arasında büyük farklılıklar göstermiştir.

Zenginleşme, bir bitki tarafından alınan bir kirletici maddenin hızlı bir şekilde parçalanmadığı durumlarda meydana gelir; bitkide birikme ile sonuçlanır. Zenginleştirme katsayısı $(\mathrm{EF})$, bir bitki türünün fitoremediasyon potansiyelini göz önüne alındığında önemli bir faktördür. EF $>1$, bitkinin metal iyonlarını topraktan akümüle etme ve onu havadan parçalara taşıma yeteneğini gösterir (Ghavri ve ark., 2013; Galal ve Shehata, 2015).

\section{Tartışma ve Sonuç}

Toprakta izin verilebilir sınır nikel değerleri göre $35 \mathrm{mgkg}^{-1}$ iken bitkide $10 \mathrm{mgkg}^{-1} \mathrm{dır}$. Fe değeri, FAO/WHO (2003) standardına göre sınır değer $30 \mathrm{mgkg}^{-1}$, toprakta izin verilebilir sınır demir $\left(\mathrm{Fe}^{+2}\right)$ değeri $50 \mathrm{mgkg}^{-1}$ olarak; bitkide izin verilebilir demir sınır değerleri ise 50-150 $\mathrm{mgkg}^{-1}$ arasinda olduğu bildirilmektedir (Yücel ve ark., 2010; Fergusson, 1990). Carrigan ve Erwin (1951)'e göre toprakların toplam Co içeriği 1-40 $\mathrm{mgkg}^{-1}$, ekstrakte edilebilir Co içeriği ise $0.03-0.09 \mathrm{mgkg}^{-1}$ arasında bulunmaktadır. Araştırıcılara göre tarım topraklarında ekstrakte edilebilir Kobalt'ın toksisite sınır değeri $0.09 \mathrm{mgkg}^{-1}$ olarak belirlenmiş̧tir. Bitki ve toprakta $\mathrm{Mn}$ sınır değerleri $100 \mathrm{mgkg}^{-1}$ olarak belirlenmiştir (Alvarenga ve ark., 2007).

Bu çalışmada, Ni bitki ve toprakta toksik sınıın altında, Fe bitkide ve toprakta sınır değerin üstüne, Co bitkide ve toprakta sınır değerin üstüne, $\mathrm{Mn}$ ise toprakta sınır değerinin altında iken şehir içi, yol kenarı ve kenar semtte toksik sınırın üstünde bulunmuştur (Tablo 6) Toprak pH’sı yol kenarında bazik diğer alanlarda nötr-hafif bazik olarak bulunmuştur.

Nötr ve yüksek toprak pH'ı, toprak toksik elementlerini stabilize edebilir, böylece toprak toksik elementlerinin etkilerini azaltır (Badr ve ark., 2012 ). Ayrıca elementlerin topraktan bitkiler tarafından alınabilirliği çok çeşitli faktörlere bağlıdır. Bitkinin genetik yapısı, ilgili elementin toprağın bulundurma kapasitesine, elementlerin toprakta mobil ya da inmobil olması, elementin su içerisinde çözünmesi önemli faktörler arasında sayılabilir. Türünün yaprak ve kökünde biriken ağır metal miktarları 'na göre bitkinin gövdesinde ki ağır metal birikimininden daha fazla olduğu görülmektedir. Smical ve ark. (2008) bitkilerde ağır metal daha çok köklerde daha sonra diğer organlarda biriktiğini bildirmişlerdir. L. draba Ni ve Fe'nin köklerde birikimi, Co ve Mn ise yaprakta birikimin daha yüksek olduğu görülmektedir. Fitostabilizasyon, kirleticilerin topraktaki göçünü en aza indirmek için kullanılabilir (Susarla ve ark., 2002). Yol kenarındaki atmosferik partiküllerde önemli miktarda ağır metal birkirimine neden olabilmektedir (Johansson ve ark., 2009). Yapraklarda Co ve Mn'nin yüksek oluşunun bir nedeni de atmosferik kaynaklı olabilir.

Bir bitkinin hiperakümülatör olabilmesi için, normal bitkilerde ölçülenden 100 kat daha fazla metal biriktirme kabiliyetine sahip bitkiler olarak tanımlanmaktadır. Hiperakümülatör bir bitki 10 ppm'den fazla $\mathrm{Hg}, 100$ ppm'den fazla Cd, 1000 ppm'den fazla Co, Cr, $\mathrm{Cu}$, ve $\mathrm{Pb}$ ve 10.000 ppm'den fazla Ni ve Zn' yu bünyesine alabilmektedir (Baker ve Broks, 1989). L.draba çalışlan elementlerin hiç birinde 100-1000 kat akümülasyon gerçekleştirememiştir. Ancak Ni ve Fe bakımından yüksek akümülasyon tespit edilmiştir.

$\mathrm{Bu}$ araştırmada EF değerleri 2'nin üstünde bulunmuştur. EF değerleri arttıkça, antropojenik etkinin katkısı da artar. EF'ler genellikle yerel arka plan değerleri kullanılarak değerlendirilmiştir. EF>2 değerleri zenginleştirilmiş numunelere işaret eder (Mingorance ve ark., 2007).

$\mathrm{BCF}$, bitkilerde metal birikim etkinliğinin değerlendirilmesi için ve TF ise bitkinin köklerinden üst organlarına metallerin yerini değiştirme kapasitesini değerlendirmek için kullanılabilir. L. draba türü $\mathrm{Ni}$, Co ve $\mathrm{Mn}$ elementleri bakımından yüksek biriktirme oranına sahiptir. Türün bu elementler bakımından iyi bir akümülatör olabileceğini düşünülmektedir.

Fitoremediasyon amacıyla kullanılan bitkilerin performanslarının değerlendirilmesi amacıyla kullanılan Baker Teorisine göre bitkiler, iyi toplayıcılar ve kökte tutucular olarak 2'ye ayrılmaktadır. Baker teorisine göre iyi bir toplayıcı bitki, toprak üstü aksamında yüksek oranda element biriktirebilen bitki olarak tanımlanmaktadır. Buna göre toprak üstü aksamında biriken element miktarının köklerinde biriken element miktarına oranı 1'den yüksek olan bitkiler iyi toplayıcı bitkiler olarak sınıflandırılmaktadır. Bu oranın 1 'den düşük olduğu bitkiler ise köklerinde tuttukları elementleri, toprak üstü aksamına iyi iletemeyen bitkiler (kökte tutucular) olarak değerlendirilmektedir (Baker ve Brooks, 1989).

Baker Teorisine göre iyi toplayıcılar fitoekstraksiyon yönteminde, kökte tutucular ise fitostabilizasyon yönteminde kullanılabilmektedir (Vanl1, 2007). Çalışmamızda L. draba türü araştırılan $\mathrm{Ni}$, Co ve Mn elementlerinde TF oranı 1> den büyük olduğu için iyi toplayıcı grubuna girmektedir. L.draba Ni ve Fe'nin köklerde birikimi, Co ve Mn ise yaprakta birikimin daha yüksek olduğu görülmektedir.

Nouri ve ark. (2011), İran'da maden kaynaklarına yakın alanlarda yayılış gösteren türlerin biyoremediasyon kapasitelerini araştırdıkları çalışmada $L$. draba' da Mn kökte $128 \mathrm{mgkg}^{-1}$ gövdede ise $261 \mathrm{mgkg}^{-1}$, BCF değeri 0.43 , TF değeri 0.23 , Fe değerini ise 
kökte $1.306 \mathrm{mgkg}^{-1}$, gövdede $2.557 \mathrm{mgkg}^{-1}$, BCF değeri 0.20 , TF ise 0.84 bulmuşlardır. Bitkinin hiperakümülatörlük özelliğinin düşük olduğunu bildirmişlerdir. Bizim çalışmamızda ise TF ve BCF değerleri yüksek bulunmuş olup bitkinin hiperakümülatörlük özelliğinin yüksek olduğu tespit edilmiştir. Riahi ve ark. (2015) $L$. draba'nın $\mathrm{Zn}$ ve $\mathrm{Ag}$ için, Cheraghi ve ark. (2011) $\mathrm{Cu}$ elementi için hiperakümülatör olduğunu bildirmişlerdir. Georgieva ve ark. (2015) Bulgaristan'da yaptıkları çalışmada $L$. draba'nın aşırı derecede kirlenmiş alandaki hiperakümülasyon seviyelerinin yüksek olduğunu, $\mathrm{Pb}$ ve Cd'yi yüksek seviyede biriktirdikleri, Micevska ve ark. (2019) Ni ve Fe'nin atmosferdeki girdilerinin çevreye değerlendirilmesi için potansiyel bir tür olduğunu bildirmişlerdir. Sonuç olarak bitkinin yaprakları ve köklerinde yüksek BF ve TF değerleri gözlemlendiği için, ağır metal kirliliği içeren toprakların temizlenmesinde bu bitkilerin metal biriktirici bitkiler (hiperakümülatör) olarak kullanılabilinir (Brooks, 1998).

Fitoremediasyon teknolojisi, kirlenmiş toprakların temizlenmesinde biyolojik tabanlı ve düşük maliyetlidir. Ayrıca toprağın kazılarak yerinden alınmaması önemli bir maliyet azaltıcı avantaj olarak göze çarpmaktadır. Hiperakümülatör bitkiler, ağır metallerle kirlenmiş alanların fitoremediasyonu için bu bitkilerin potansiyel kullanımlarından dolayı son yıllarda artan ilgi görmektedir. Araştırmamız türün doğal olarak yayılış gösterdiği alanlarda yapılmıştır. Bitkinin akümülasyon kapasitesini arttırmak amacıyla şelat destekli bir şekilde kültüre alınarak kontrollü sera deneme çalışmaları yapılması önerilmektedir.

\section{Kaynakça}

Afzal, M., Ali, M. I., Munir, M. A., Ahmad, M., Mahmood, Z., Sharif, M. N., \& Aslam, M. (2016). Genetic association among morphological traits of Lepidium draba. Bulletin of Biological and Allied Sciences Research, 1(1).

Alvarenga, P., Palma, P., Gonçalves, A. P., Fernandes, R. M., Cunha-Queda, A. C., Duarte, E., \& Vallini, G. (2007). Evaluation of chemical and ecotoxicological characteristics of biodegradable organic residues for application to agricultural land. Environment International, 33(4), 505-513.

Asri, F. Ö., \& Sönmez, S. (2006). Ağır metal toksisitesinin bitki metabolizması üzerine etkileri. Derim, 23(2), 36-45.

Badr, N., Fawzy, M., \& Al-Qahtani, K. M. (2012). Phytoremediation: An ecological solution to heavy-metal-polluted soil and evaluation of plant removal ability. World Applied Sciences Journal, 16(9), 1292-1301.

Baker, A. J. M., \& Brooks, R. (1989). Terrestrial higher plants which hyperaccumulate metallic elements. A review of their distribution, ecology and phytochemistry. Biorecovery, 1(2), 81-126.

Barbieri, M. (2016). The importance of enrichment factor (EF) and geoaccumulation index (Igeo) to evaluate the soil contamination. $J$ Geol Geophys, 5(237), 2.

Blaylock, M. J., Salt, D. E., Dushenkov, S., Zakharova, O., Gussman, C., Kapulnik, Y., ... \& Raskin, I. (1997). Enhanced accumulation of $\mathrm{Pb}$ in Indian mustard by soil-applied chelating agents. Environmental Science \& Technology, 31(3), 860-865.

Brooks, R. R. (1972). Geobotany and biogeochemistry in mineral exploration.

Brooks, R. R. (1998). Plants that Hyperaccumulate Heavy Metals: Their Role in Phytoremediation, Microbiology, Archaeology. Mineral Exploration and Phytomining. Wallingford, UK: CAB International.

Buat-Menard, P., \& Chesselet, R. (1979). Variable influence of the atmospheric flux on the trace metal chemistry of oceanic suspended matter. Earth and Planetary Science Letters, 42(3), 399-411.

Carrigan, R. A., \& Erwin, T. C. (1951). Cobalt Determination in Soils by Spectrographic Analysis Following Chemical Preconcentration 1. Soil Science Society of America Journal, 15(C), 145-149.

Cheraghi, M., Lorestani, B., \& Yousefi, N. (2011). Introduction of hyperaccumulator plants with phytoremediation potential of a leadzinc mine in Iran. World Acad Sci Eng Technol, 77, 163-8.

Demirayak, A., Kutbay, H. G., Sürmen, B., Kılıç, D . (2019). Arsenic accumulation in some natural and exotic tree and shrub species in Samsun Provience (Turkey). Anatolian Journal of Botany, 3(1), 13-17.

Doğan, M. (2019). Effect of cadmium, chromium, and lead on micropropagation and physio-biochemical parameters of Bacopa monnieri (L.) Wettst. cultured in vitro. Rendiconti Lincei. Scienze Fisiche e Naturali, 30(2), 351-366.

Doğan, M., Karataş, M., \& Aasim, M. (2018). Kadmiyum, Krom ve Kurşunun Ceratophyllum demersum L. ve Pogostemon erectus (Dalzell) Kuntze Üzerine Fitotoksisitesinin Değerlendirilmesi. Karaelmas Science and Engineering Journal, 8(2), 543-550.

FAO/WHO (2003). Codex Alimentarius International Food Standards Codex Stan-179, Codex Alimentariuscommission.

Fergusson, J. E. (1990). Heavy elements: chemistry, environmental impact and health effects. Pergamon.

Galal, T. M., \& Shehata, H. S. (2015). Bioaccumulation and translocation of heavy metals by Plantago major L. grown in contaminated soils under the effect of traffic pollution. Ecological Indicators, 48, 244-251.

Garbisu, C., Allica, J. H., Barrutia, O., Alkorta, I., \& Becerril, J. M. (2002). Phytoremediation: a technology using green plants to remove contaminants from polluted areas. Reviews on Environmental Health, 17(3), 173-188.

Georgieva, S., Atanassova, J., Dinev, N. (2015). Metal hyperaccumulation in Cardaria draba (L.) Desv.(Brassicaceae) and heavy metal effects on the nematodes and a weevil associated with the plant roots in sites near a non-ferrous metal smelter in Bulgaria. Soil Sci Agroche. Ecol, 49, 55-64.

Ghavri, S. V., Bauddh, K., Kumar, S., \& Singh, R. P. (2013). Bioaccumulation and translocation potential of Na+ and K+ in native weeds grown on industrially contaminated soil. Int J ChemTech Res, 5(4), 1869-1875.

Johansson, C., Norman, M., \& Burman, L. (2009). Road traffic emission factors for heavy metals. Atmospheric Environment, 43(31), 4681-4688.

Kabata-Pendias, A., \& Dudka, S. (1991). Trace metal contents ofTaraxacum officinale (dandelion) as a convenient environmental indicator. Environmental Geochemistry and Health, 13(2), 108-113.

Kaçar, B., \& Katkat, V. (2010). Bitki Besleme (Plant Nutrition)(5. Baskı). Nobel Yayın Dağıtım.

Kalender, L., \& Alçiçek, Ö. N. (2016). Astragalus angustifolius, Artemisia ve Juncus effusus' un Uranyum ve Toryum için Biyoakümülatör Özellikleri. Firat Üniversitesi Mühendislik Bilimleri Dergisi, 28(2), 267-273. 
Kılıç, D. (2019). Investigation of heavy metal accumulation and biomonitoring of Calepina irregularis species growing in Amasya (Turkey) province. Anatolian Journal of Botany, 3(2), 44-50.

Ladislas, S., El-Mufleh, A., Gérente, C., Chazarenc, F., Andrès, Y., \& Béchet, B. (2012). Potential of aquatic macrophytes as bioindicators of heavy metal pollution in urban stormwater runoff. Water, Air, \& Soil Pollution, 223(2), 877-888.

Luu, T. D., Truong, P., Mammucari, R., Tam, T., \& Foster, N. (2009). Vetiver grass, Vetiveria zizanioides: a choice plant for phytoremediation of heavy metals and organic wastes. International Journal of Phytoremediation, 11(8), 664-691.

Macek, T., Kotrba, P., Svatos, A., Novakova, M., Demnerova, K., \& Mackova, M. (2008). Novel roles for genetically modified plants in environmental protection. Trends in biotechnology, 26(3), 146-152.

McGrath, S. P., Zhao, F. J., \& Lombi, E. (2001). Plant and rhizosphere processes involved in phytoremediation of metal-contaminated soils. Plant and Soil, 232(1-2), 207-214.

Mellem, J. J., Baijnath, H., \& Odhav, B. (2012). Bioaccumulation of $\mathrm{Cr}, \mathrm{Hg}, \mathrm{As}, \mathrm{Pb}, \mathrm{Cu}$ and $\mathrm{Ni}$ with the ability for hyperaccumulation by Amaranthus dubius. African Journal of Agricultural Research, 7(4), 591-596.

Micevska, O., Hristovski, S., \& Melovski, L. (2019). The impact of the ferro-nickel smelter's fugitive dust emission on heavy metal content in soils and whitetop (Lepidium draba 1.) in Kavadarc1, Republic of Macedonia. Environmental pollution, 15, 16.

Mingorance, M. D., Valdes, B., \& Oliva, S. R. (2007). Strategies of heavy metal uptake by plants growing under industrial emissions. Environment International, 33(4), 514-520.

Müller, G. (1969). Index of geoaccumulation in sediments of the Rhine River. Geojournal, 2, 108-118.

Nouri, J., Lorestani, B., Yousefi, N., Khorasani, N., Hasani, A. H., Seif, F., \& Cheraghi, M. (2011). Phytoremediation potential of native plants grown in the vicinity of Ahangaran lead-zinc mine (Hamedan, Iran). Environmental Earth Sciences, 62(3), 639-644.

Oven, M., Grill, E., Golan-Goldhirsh, A., Kutchan, T. M., \& Zenk, M. H. (2002). Increase of free cysteine and citric acid in plant cells exposed to cobalt ions. Phytochemistry, 60(5), 467-474.

Özkul, C., Acar, R. U., Köprübaşı, N., Er, A. E., Kızılkaya, H. İ., Metin, M., \& Şenel, M. N. (2018). Altıntaş (Kütahya-Türkiye) ovası tarım topraklarında ağır metal kirliliğinin araştırılması, öncel çalışma. Uygulamalı Yerbilimleri Dergisi, 17(1), 13-26.

Padmavathiamma, P. K., \& Li, L. Y. (2007). Phytoremediation technology: hyper-accumulation metals in plants. Water, Air, and Soil Pollution, 184(1-4), 105-126.

Reeves, R. D., \& Brooks, R. R. (1983). Hyperaccumulation of lead and zinc by two metallophytes from mining areas of Central Europe. Environmental pollution series A, Ecological and Biological, 31(4), 277-285.

Riahi, M. A., Nasiri, B. M., Yousefi, K., \& Mohammadi, M. (2015). Investigation of the ability of Lepidium draba L. seedlings in zinc and silver ions absorption and effect of the ions on morphological and biochemical characteristics of the seedlings. Journal of Cell \& Tissue, 6(1), 59-70.

Salt, D. E., \& Rauser, W. E. (1995). MgATP-dependent transport of phytochelatins across the tonoplast of oat roots. Plant Physiology, 107(4), 1293-1301.

Scurfield, G. (1962). Cardaria Draba (L.) Desv. Journal of Ecology, 50(2), 489-499.

Smical, A. I., Hotea, V., Oros, V., Juhasz, J., \& Pop, E. (2008). Studies on transfer and bioaccumulation of heavy metals from soil into lettuce. Environmental Engineering and Management Journal, 7(5), 609-615.

Susarla, S., Medina, V. F., \& McCutcheon, S. C. (2002). Phytoremediation: an ecological solution to organic chemical contamination. Ecological Engineering, 18(5), 647-658.

Sutherland, R. A. (2000). Bed sediment-associated trace metals in an urban stream, Oahu, Hawaii. Environmental Geology, 39(6), 611-627.

Van Der Ent, A., Echevarria, G., \& Tibbett, M. (2016). Delimiting soil chemistry thresholds for nickel hyperaccumulator plants in Sabah (Malaysia). Chemoecology, 26(2), 67-82.

Vanlı, Ö. (2007). Pb, Cd, B Elementlerinin Topraklardan Şelat Destekli Fitoremediasyon Yöntemiyle Giderilmesi. (Doctoral dissertation, Fen Bilimleri Enstitüsü).

Vatamaniuk, O. K., Mari, S., Lu, Y. P., \& Rea, P. A. (2000). Mechanism of heavy metal ion activation of phytochelatin (PC) synthase blocked thiols are sufficient for PC synthase-catalyzed transpeptidation of glutathione and related thiol peptides. Journal of Biological Chemistry, 275(40), 31451-31459.

Yanqun, Z., Yuan, L., Jianjun, C., Haiyan, C., Li, Q., \& Schvartz, C. (2005). Hyperaccumulation of Pb, Zn and Cd in herbaceous grown on lead-zinc mining area in Yunnan, China. Environment International, 31(5), 755-762.

Yoon, J., Cao, X., Zhou, Q., \& Ma, L. Q. (2006). Accumulation of Pb, Cu, and $\mathrm{Zn}$ in native plants growing on a contaminated Florida site. Science of The Total Environment, 368(2-3), 456-464.

Yücel, E., Edtrnelioglau, E., Soydam, S., Celik, S., Colak, G. (2010). Myriophyllum spicatum(Spiked water-milfoil) as a biomonitor of heavy metal pollution in Porsuk Stream/Turkey. Biological Diversity and Conservation, 3(2), 133-144.

Zayed, A., Gowthaman, S., \& Terry, N. (1998). Phytoaccumulation of trace elements by wetland plants: I. Duckweed. Journal of Environmental Quality, 27(3), 715-721. 